\title{
Learning environment, attitudes and anxiety across the transition from primary to secondary school mathematics
}

\begin{abstract}
Past research has revealed that, relative to primary-school students, high-school students have less-positive attitudes to mathematics and perceive their classroom environments and teacher-student relationships less favourably. This study involved the transition experience of 541 students in 47 classes in 15 primary (year 7) and secondary (year 8) government and Catholic schools in metropolitan and regional South Australia. Scales were adapted from three established instruments, namely, the What Is Happening In this Class? (WIHIC), Test of Mathematics Related Attitudes (TOMRA) and Revised Mathematics Anxiety Ratings Scale (RMARS), to identify changes across the transition from primary to secondary school in terms of the classroom learning environment and students' attitude/anxiety towards mathematics. Relative to year 7 students, year 8 students reported less Involvement, less positive Attitude to Mathematical Inquiry, less Enjoyment of Mathematics and greater Mathematics Anxiety. Differences between students in Years 7 and 8 were very similar for male and female students, although the magnitude of sex differences in attitudes was slightly different in Years 7 and 8.
\end{abstract}

Keywords Anxiety $\cdot$ Attitudes $\cdot$ Learning environments $\cdot$ Mathematics

Transition · What Is Happening In this Class? (WIHIC)

\section{Introduction}


The transition between primary and secondary schooling, particularly from year 7 to year 8 , was the focus of this study involving 541 students from year 7 (primary) and year 8 (secondary) schools from metropolitan and regional South Australia. Our goal was to identify changes across transition in classroom learning environments and students' attitude/anxiety towards mathematics by utilising shortened forms of the What Is Happening In this Class? (WIHIC) to assess the learning environment, an attitude questionnaire modified from the Test of Mathematics Related Attitudes (TOMRA), and a Mathematics Anxiety Measure (MAM) based on the Mathematics Anxiety Inventory (MAI) and the Abbreviated Math Anxiety Scale (AMAS).

\section{Perspectives or theoretical framework}

Transition

The transition from primary to secondary schooling has been of interest to researchers for several decades, but it has picked up momentum from the 1990s to the present time. Past research has revealed that student-teacher relationships in mathematics classes deteriorated after the transition from the primary to secondary sector (Feldlaufer, Midgley and Eccles 1988; Ferguson and Fraser 1999; Midgley, Feldlaufer and Eccles 1989). Noyes (2006, p. 44) pointed out that, regarding previous studies, there have been "too few that examine the impact of the transfer process upon learners of mathematics". Perso (2005, p. 28) views this transition as involving "environmental changes from a closeted 'childish/feminine' environment to an independent 'adult/masculine' environment'. Hayes and Chodkiewicz (2006) reported an increase in girls' depression and hostility over this transition, whereas 
Maher (2010) believes that the unknown workload expected by secondary-school teachers is a cause of student anxiety.

Several studies revealed that this transition period is associated with a decline in students' achievement in mathematics (Anderman and Midgley 1997; Rice 1997, 2001). Bru et al. (2010) cite several studies undertaken in Norway that show that elementary-school children have more positive perceptions of their learning environments than their secondaryschool counterparts. Other studies reporting negative changes in learning environments across transition include Eccles et al. (1993), Anderman and Midgley (1997) and Feldlaufer et al. (1988).

In relation to mathematics, Midgley, Feldlaufer and Eccles (1989) reported that changes in classroom environment during this transition were attributable to students' expectations and values in mathematics. Several other researchers (Ashton 2008; Galton and Morrison 2000; Zeedyk et al. 2003) attribute the anxiety experienced by students during this transition to fear of bullying, getting lost, not making friends, not coping with work, new routines, etc.

Two prior Australian longitudinal studies focused on the primary-secondary transition. In Tasmania, Ferguson and Fraser (1999) tracked 1040 primary science students in 47 feeder schools to 16 linked secondary schools. Generally there was a deterioration across transition in student-teacher relationships, but these changes varied somewhat with student gender and the size of the primary school from which students were exiting. In South Australia, when Hine (2001) tracked 311 students who exited grade 7 and transitioned to grade 8 , secondary classroom environments generally were perceived less favourably for the two school subjects of mathematics and English. Hine attributed this trend to rapid lesson turnover, multiple specialist teachers and larger school sizes, which were associated with a perceived increase in alientation. 
Zeedyk et al. (2003, p. 68) make the following statement in relation to this primary to secondary transition: "This period is regarded as one of the most difficult in pupils' educational careers, and success in navigating it can affect not only children's academic performance, but their general sense of well-being and mental health." The literature reviewed above justifies the significance of our study of the changes in learning environment and students' attitudes and anxiety associated with the transition from primary to secondary school mathematics.

Learning environments

Research into classroom learning environments blossomed in the West over 40 years ago, particularly in the USA during the 1960s, but its genesis was in the 1930s in the ideas formulated in business settings by pioneers such as Lewin and Murray. Lewin's (1936) field theory postulated that $B=\mathrm{f}(P, E)$, or behaviour $(B)$ is a function of the person $(P)$ and environment $(E)$. He was also responsible for coining the terms alpha press (the environment as observed by an external observer) and beta press (the environment as perceived by milieu inhabitants).

Murray (1938) took this behaviour-person-environment relationship further by introducing the idea of environmental press and proposing a needs-press model in which situational variables in the environment account variance in behaviour. This needs-press model essentially highlights the critical importance of the individual and the individual's interaction with the environment. "An individual's behaviour is affected internally by characteristics of personality and externally by the environment itself" (Wolf and Fraser 2008, p. 322).

During the 1950s, Stern and colleagues realised that there are differences between an 
individual's perceptions, a group's perceptions and the perceptions of an external observer of the same environment (Stern, Stein and Bloom 1956). Stern and colleagues also differentiated private beta press (the individual's view of an environment) from consensual beta press (the shared view of a group as a whole).

Walberg and Anderson's (1968) work with Harvard Project Physics, especially development of the Learning Environment Inventory (LEI), was pioneering and still influences instrument development today (Dorman 2008). In the 1970s, Moos (1974) developed a classification of aspects of human environments into three dimensions, namely, relationship, personal development, and system maintenance and change. According to Dorman (2003), this was an important and sustaining development in the field of learning environments that influenced the development of various learning environment questionnaires starting with the Classroom Environment Scale (CES) (Moos \& Trickett 1974).

Learning environments research then spread to the Netherlands where Wubbels and collaborators developed the Questionnaire on Teacher Interaction (QTI, Goh and Fraser 2000; Wubbels and Brekelmans 2012; Wubbels \& Levy 1991). During this period, in Australia, Fraser and colleagues created numerous hybrid varieties of evaluation instruments, such as the Individualised Classroom Environment Questionnaire (ICEQ, Fraser 1982), Science Laboratory Environment Inventory (SLEI, Fraser, Giddings and McRobbie 1995), Constructivist Learning Environment Survey (CLES, Taylor, Fraser and Fisher, 1997), What Is Happening In this Class? (WIHIC, Aldridge, Fraser and Huang 1999) and TechnologyRich Outcomes-Focused Learning Environment Inventory (TROFLEI, Aldridge and Fraser 2008).

According to Dorman $(2003,2008)$, the most-frequently used classroom environment questionnaire currently worldwide is the What Is Happening In this Class? (WIHIC, Aldridge 
et al. 1999; Helding and Fraser 2013; Zaragoza and Fraser 2017). For example, Khine et al. (in press) tabulated 24 studies that had used the WIHIC in Australia, China, Greece, Indonesia, Israel, Jordan, Qatar, Singapore, Turkey, Uganda, the United Arab Emirates and the USA. Also, Fraser (2012) tabulated 21 studies that had used the WIHIC in Australia, Taiwan, the UK, Canada, Indonesia, Singapore, India, South Africa, Korea, the United Arab Emirates and the USA. Our study of transition included the use of a modified version of the WIHIC.

Past classroom environment research reviewed by Fraser $(2012,2014)$ includes the use of learning environment dimensions: in investigations of associations between the classroom environment and student outcomes (Fraser and Butts 1982; Fraser and Kahle 2007; McRobbie and Fraser 1993); as criteria of effectiveness in evaluating educational programs (e.g. Cohn and Fraser 2016; Koh and Fraser 2014; Spinner and Fraser 2005); in identifying the classroom environments created by exemplary teachers (Fraser and Tobin 1987); in investigating differences between students' actual and preferred learning environments (Byrne, Hattie and Fraser 1986; Fraser and Fisher 1983); and in the work of school psychologists (Burden and Fraser 1993).

An important practical application of learning environment questionnaires involves providing feedback to teachers in action research aimed at improving their classroom environments. This approach was initiated by Fraser (1981a), was the focus of Fraser and Aldridge's (2017) recent literature review, and has been successfully implemented by Aldridge and Fraser (2008), Aldridge, Fraser and Sebela (2004) and Yarrow, Millwater and Fraser (1997).

Attitudes and anxiety towards mathematics 
In psychology, attitudes have been considered central for a long time (Allport 1935) and, in science and mathematics education specifically, Aiken (2002) reviewed research on attitudes. The conceptualisation, measurement and investigation of students' attitudes to science has been a past, and is a continuing, interest internationally (Khine 2015; Kind and Barmby 2011; Tytler and Osborne 2012). However, numerous long-standing problems in measuring attitudes to science (e.g. low reliability; combining conceptually-distinct constructs to form a unidimensional scale) have been identified by Munby (1997), Osborne, Simons and Collins (2003) and Kind, Jones and Barmby (2007).

Interest in mathematics anxiety evolved during the 1950s with the coining of the term 'mathemaphobia' by Gough (1954). Another term for this type of anxiety is 'mathophobia' or 'numerophobia' which Crypton (1981, p. 121) describes as a "fear and loathing of dealing with even the most elementary numbers and numerical functions". Hunt (1985, p. 32) claims: "The term maths anxiety has been used to describe the panic, helplessness, paralysis and mental disorganisation that arises among some people when they are required to solve a mathematical problem". Guillen (1984, p. 2) states that "math anxiety is the pathological dread and unabashed humility that mathematics evokes in hundreds of millions of people". Catlioglu, Birgin, Costu and Gurbuz (2009, p. 1578) claim that "feelings of anxiety can lead to panic, tension, helplessness, fear, distress, shame, inability to cope, sweaty palms, nervous stomach, difficulty breathing, and loss of ability to concentrate".

\section{Research Questions}

1. Do differences exist between primary and secondary schools in students' views of their mathematics classrooms in terms of: 

a. Perceptions of the learning environment?
b. Attitude and anxiety towards mathematics?

2. Are any differences existing between students in years 7 and 8 similar or different for males and females?

\section{Methods}

As discussed below, our study utilised four 8-item scales from the WIHIC (Student Cohesiveness, Teacher Support, Involvement and Cooperation) to assess learning environment, two 10-item scales from the TOMRA (Attitude to Mathematical Inquiry and Enjoyment of Mathematics Lessons) to assess students' attitudes and an 8-item mathematics anxiety scale.

WIHIC (What Is Happening In this Class?)

The 56-item WIHIC comprising seven scales was modified to form a 32-item instrument by removing three scales (Investigation, Task Orientation and Equity) of lesser relevance to our study. This instrument has a five-point frequency response scale (Almost Never, Seldom, Sometimes, Often, Almost Always). The Student Cohesiveness scale measures the extent to which students know, help and are supportive of one another. The Teacher Support scale assesses the extent to which the teacher helps, befriends, trusts and shows interest in students. The Involvement scale assesses the extent to which students have attentive interest, participate in discussions, do additional work and enjoy the class. The Cooperation scale gauges the extent to which students learn cooperatively on learning tasks. 
The WIHIC, originally developed by Fraser, McRobbie \& Fisher (1996), has been used extensively throughout the world in a variety of research applications and many studies have attested to its validity and reliability. This was one of the main reasons for selecting it for our study. A review of the literature shows that the WIHIC has demonstrated good validity and reliability in studies such as:

- Dorman (2003) with 3980 secondary mathematics students in Australia, Canada and Britain

- Dorman (2008) with 978 secondary students in Queensland, Australia

- Aldridge and Fraser (2000) with 1081 middle-school science students in Australia and 1879 students in Taiwan

- Fraser, Aldridge and Adolphe (2010) with 1161 secondary-school science students in Australia and Indonesia

- Charalampous and Kokkinos (2017) with six teachers and 24 students in Greek elementary classrooms

- Chipangura and Aldridge (2016) with 365 high-school mathematics students in Western Australia

- Khine et al. (in press) with 251 first-year university science students in Myanmar

- 1097 Grade 7 and 8 science students in New York State (Cohn and Fraser, 2016)

- Zaragoza and Fraser (2017) with 765 Grade 5 students in Florida

- Yang (2015) with 749 Grade 7, 842 Grade 8 and 864 Grade 9 mathematics students in China

- Singh and McNeil (2014) with 73 secondary students in Hawaii and 70 students in Singapore

- 763 college students in United Arab Emirates (MacLeod and Fraser, 2010) 
- 352 university mathematics students in the United Arab Emirates (Afari, Aldridge, Fraser and Khine, 2013)

- 1434 middle-school science students in New York (Wolf and Fraser, 2008)

- 543 grade 8 science students in Korea (Kim et al. 2000)

- 1404 students in 81 networked classes in Australia and Canada (Zandvliet and Fraser 2004))

- Allen and Fraser (2007) with 520 grade 4 and 5 students and 120 parents in South Florida

- Koul and Fisher (2005) with 1021 secondary science students in India

- Khoo and Fraser (2008) with 250 working adults in computer education centres in Singapore

- Chionh and Fraser (2009) with 2310 grade 10 geography and mathematics students in Singapore

- Ogbuehi and Fraser (2007) with 661 middle-school mathematics students in California

- Martin-Dunlop and Fraser (2008) with 525 female prospective elementary teachers from a university in California

- Wahyudi and Treagust (2004) with 1400 lower-secondary science students in Indonesia

- Waldrip, Fisher and Dorman (2009) with 150 teachers and 3000 middle-school students in Australia

- Lim and Fraser (2017) with 441 grade 6 English students in Singapore.

TOMRA (Test of Mathematics Related Attitudes)

Our modified version of TOMRA consisted of a total of 20 items from the two scales of Attitude towards Mathematics Inquiry and Enjoyment of Mathematics Lessons, which have a Likert response scale consisting of Strongly Agree, Agree, Not sure, Disagree and Strongly 
Disagree. These two scales were selected because we considered them important and fundamental to both mathematics education and the transition process. An important reason for selecting only two scales was so that all questionnaire scales could be administered in a single class period.

The Test of Science Related Attitudes (TOSRA) was originally developed by Fraser (1978, 1981b). Because of the links and similarities between science and mathematics, the TOSRA was easily able to be adapted to gauge mathematics attitudes. Like the WIHIC, the TOSRA has been widely validated and used by researchers throughout the world, which is an important reason for choosing it for our study. These various studies worldwide include those in the USA (Martin-Dunlop and Fraser 2008; Ogbuehi and Fraser 2007; Wolf and Fraser 2008), Australia and Taiwan (Aldridge, Fraser and Huang 1999) and Indonesia and Australia (Fraser, Aldridge and Adolphe 2010). Several other studies that attest to the reliability and validity of actual or modified TOSRA or TOMRA instruments have been carried out in the USA (Peiro and Fraser 2009; Spinner and Fraser 2005), Korea (Fraser and Lee 2009), Singapore (Wong and Fraser 1996) and Nigeria (Idiris and Fraser 1997).

MAM (Mathematics Anxiety Measure)

The MAM contains 8 items that students rate in terms of how anxious they would feel during the situation specified (e.g. "Reading and interpreting graphs and charts"). The response scale consists of Low Anxiety, Some Anxiety, Moderate Anxiety, Quite a Bit of Anxiety, and High Anxiety. The MAM drew its inspiration from the 24-item Mathematics Anxiety Rating ScaleRevised (MARS-R, Plake and Parker 1982) as well as the 9-item Abbreviated Math Anxiety Scale (AMAS, Hopko et al. 2003) described below. However, for the sake of economy of 
administration time, our MAM instrument drew on ideas and wording contained in the MARS-R and AMAS, but was restricted to only 8 items in total.

Since the pioneering work of Richardson and Suinn (1972) in developing the initial 98-item Math Anxiety Rating Scale (MARS), many abbreviated instruments to measure mathematics anxiety have followed. In particular, Plake and Parker (1982) constructed a 24item shortened version of the MARS which is known as the Math Anxiety Rating ScaleRevised (MARS-R). Research in mid-Western USA involving university students revealed that MARS-R displayed an alpha reliability of 0.98 and a correlation of 0.97 with the fullscale MARS. Hopko, Mahadevan, Bare and Hunt (2003) involved 1239 undergraduate students in developing a much shorter 9-item Abbreviated Math Anxiety Scale (AMAS) which revealed good to strong internal consistency reliability and validity. Furthermore, Hopko et al. (2003) believe that "the Abbreviated Math Anxiety Scale (AMAS) may represent a more parsimonious and valid approach to assess mathematics anxiety” (p. 178).

Numerous studies of mathematics anxiety with diverse groups have reported similar findings. Anxiety towards mathematics can develop because of negative classroom experiences, poor mathematics performance, negative teacher behaviours, environmental pressure and/or parental influences (Yaratan and Kasapoglu 2012). Research into mathematics anxiety among preservice teachers, including Finlayson (2014), Jackson and Leffingwell (1999) and Haciomeroglu (2013), generally has revealed that large majorities of these teachers have experienced such anxiety through certain stages in their personal lives. Causes for this type of anxiety are a lack of self-confidence, a fear of failure, teaching styles, ineffective learning practices and non-engagement of students. Also certain aspects of teacher behaviour negatively impacted on student attitudes and achievement, including angry behavior, unrealistic expectations, embarrassing students by forcing them to do difficult problems on the board, ridiculing girls for not understanding material, and insensitive and 
uncaring attitudes. Several studies also suggest that mathematics anxiety can begin at an early age (Aarnos and Perkkila 2012; Jackson and Leffingwell 1999; Ramirez et al. 2013; Scarpello 2007). Sengul and Dereli (2010) and Schact and Stewart (1990) found that the use of cartoons during teaching led to a reduction in mathematics anxiety among students. Other interesting studies into mathematics anxiety utilising innovative medical, scientific or technological approaches include the use of oral mucosal transudate (OMT, John-Henderson, Rheinschmidt and Mendoza-Denton 2015), brain-computer interface visual neuro-feedback (Verkijika and De Wet 2015), genotyping by saliva sample or buccal swab (Wang et al. 2014), functional magnetic resonance imaging (fMRI, Supekar et al. 2015; Young, Wu and Menon 2012) and transcranial direct-current stimulation (tDCS, Sarkar et al. 2014).

Further relevant past research on mathematics anxiety includes Marchis (2011) with 337 secondary-school students in Romania, a Dutch study with 207 children in grades 3 to 6 (Jansen et al. 2013), Kvedere (2014) with 3,077 Latvian $9^{\text {th }}$ grade students, Abbasi et al. (2013) with 480 high-school and pre-university students and their mathematics teachers in Iran, Al Mutawah (2015) with 1,352 grade 8-11 students in Bahrain, Primi et al. (2014) with 215 high-school students and 249 first- and second-year university psychology students in Tuscany, Italy, and a Turkish study with $1206^{\text {th }}$ grade and $1247^{\text {th }}$ grade elementary students (Olmez and Ozel 2012).

Data sources

The sample comprised 541 students from both primary (year 7) and secondary (year 8) schools in country and metropolitan South Australia, which differs from many other Australian states in that year 7 is the final year of primary school and year 8 is the first year of secondary school. The schools came from both the government and Catholic sectors. In 
total, there were 15 schools ( 5 secondary, 9 primary, 1 area) that made up the sample. (An area school is a rural or country school that caters for both secondary and primary students.) The Catholic primary school sector provided 72 (year 7) students and 189 (year 8) students, while the government sector provided 135 (year 7) and 145 (year 8) students for the sample. This resulted in a combined total of 207 (year 7) and 334 (year 8) students from both sectors, yielding a grand total of 541 students.

Three of the secondary schools were Catholic and metropolitan (two girls' schools and one co-educational school). The students from these schools mainly came from middleclass sections of the community, and represented a good cross-section of the middle-class population. Survey findings for this group thus could be generalised to other middle-class schools within the metropolitan area. The remainder of the secondary schools were government schools from regional areas and also were typical of schools within these regional areas.

In relation to the primary schools, two schools were Catholic metropolitan, two were government metropolitan and the rest comprised regional government schools. The metropolitan primary schools also represented middle-class suburbia and thus our results could be indicative of a wider middle-class population. The government schools (both primary and secondary) in our sample came from regional areas characterised by lower socioeconomic status, greater unemployment, single-parent families, welfare recipients, etc. Their results could be generalised to other schools within the particular regional areas.

\section{Results}

Preliminary checking of validity of WIHIC and attitude questionnaire 
Prior to conducting analyses to answer our main research questions, first we checked the structure of our four-scale version of the WIHIC for our South Australian sample by conducting principal axis factor analysis with varimax rotation and Kaiser normalisation. The two criteria for the retention of any item were that it must have a factor loading of at least 0.35 on its own scale and less than 0.35 on each of the other three WIHIC scales. The results of the factor analysis in Appendix A show that the factor loadings for each of the 32 WIHIC items satisfied these two criteria and therefore were retained. In fact, 24 of the WIHIC's 32 items had a factor loading exceeding 0.50 .

The bottom of Appendix A shows that the proportion of variance accounted for ranged from $4.04 \%$ to $35.98 \%$ for different WIHIC scales. The total proportion of variance was 55.26\%. The bottom of Appendix A also shows that scale eigenvalues ranged from 1.29 to 11.51 and that each eigenvalue exceeded the minimum value of 1 for a factor to be considered meaningful (Kaiser 1974).

To check the structure of the 28 attitude and anxiety items in three scales, similar principal axis factoring with varimax rotation and Kaiser normalisation was undertaken for our sample of 541 students. The two attitude scales (Attitude to Mathematical Inquiry and Enjoyment of Mathematics Lessons), each comprising 10 items, were derived from the TOMRA. The mathematics anxiety scale consists of 8 items and forms the Mathematics Anxiety Measure (MAM). The results of the factor analysis are shown in Appendix B. Again, the criteria for the retention of any item were that it must have a factor loading of at least 0.35 with its own scale and less than 0.35 with the other scale(s). Appendix B shows that all of the 28 items satisfied the requirements and therefore were retained. Of the 28 factor loadings in Appendix B, 19 exceeded 0.50 in magnitude.

The bottom of Appendix B shows that the proportion of variance accounted for ranged from $7.46 \%$ to $29.59 \%$ for the different attitude and anxiety scales. The total 
proportion of variance was $48.81 \%$. The bottom of Appendix B shows that scale eigenvalues ranged from 2.08 to 8.28 , thus satisfying the cutoff criterion of 1 for meaningfulness.

The internal consistency reliability of each WIHIC and attitude/anxiety scale was checked using Cronbach's alpha coefficient. An acceptable level of reliability of an instrument is 0.70 or greater (Urdan 2010, p. 178). For our sample of 541 students, the last row of Appendices A and B show that the alpha coefficient for the four WIHIC scales ranged from 0.83 to 0.90 and for the three attitude/anxiety scales ranged from 0.65 to 0.96 .

Overall the results in Appendices A and B support the satisfactory factorial validity and internal consistency reliability of all learning environment and attitude/anxiety scales when used with our sample of students in South Australia.

Differences between year 7 and 8 and whether grade-level differences are different for males and females

Our first research question focused on a comparison of Year 7 students (prior to transition) with Year 8 students (after transition) in terms of learning environment perceptions and attitudes/anxiety. Our second research question involved whether any differences existing between students in Years 7 and 8 were similar or different for male and female students.

Both of these research questions were investigated simultaneously by conducting a two-way MANOVA for our whole sample of 541 students with our four learning environment scales and three attitude/anxiety scales as the set of seven dependent variables. Grade level and sex were the two independent variables. The presence or absence of a statistically significant interaction between grade level and sex was used to identify whether grade-level differences were different or similar for males and females.

Initially conducting MANOVA for the entire set of seven dependent variables reduced the Type I error rate associated with conducting separate univariate tests for 
individual dependent variables. Using Wilks' lamda criterion, MANOVA revealed significant results for grade level, sex and the grade-by-sex interaction. Therefore we interpreted the ANOVA results for each dependent variable.

Table 1 Two-way MANOVA/ANOVA for grade-level and sex differences in each learning environment and attitude/anxiety scale

\begin{tabular}{|c|c|c|c|c|c|c|}
\hline \multirow[t]{2}{*}{ Scale } & \multicolumn{2}{|c|}{ Grade level } & \multicolumn{2}{|c|}{ Sex } & \multicolumn{2}{|c|}{$\begin{array}{c}\text { Grade } x \text { sex } \\
\text { interaction }\end{array}$} \\
\hline & $F$ & $\mathrm{Eta}^{2}$ & $F$ & Eta $^{2}$ & $F$ & $\mathrm{Eta}^{2}$ \\
\hline \multicolumn{7}{|l|}{ Learning Environment } \\
\hline Student Cohesiveness & 0.86 & 0.00 & $24.27 * *$ & 0.04 & 0.87 & 0.00 \\
\hline Teacher Support & 0.54 & 0.00 & 1.72 & 0.00 & 1.46 & 0.00 \\
\hline Involvement & $11.56 * *$ & 0.02 & 2.19 & 0.00 & 3.08 & 0.00 \\
\hline Cooperation & 1.09 & 0.00 & $16.24 * *$ & 0.03 & 0.04 & 0.00 \\
\hline \multicolumn{7}{|l|}{ Attitudes/Anxiety } \\
\hline Attitude to Maths Inquiry & $21.09 * *$ & 0.04 & 0.94 & 0.00 & $6.11 *$ & 0.01 \\
\hline Enjoyment of Mathematics & $30.93 * *$ & 0.05 & $9.49 * *$ & 0.02 & $5.42 *$ & 0.01 \\
\hline Mathematics Anxiety & $10.68 * *$ & 0.02 & $7.90 * *$ & 0.01 & 0.09 & 0.00 \\
\hline
\end{tabular}

Sample Size: Males $=209$ and Females $=332$; Grade: $7=207$ and Grade: $8=334$

Table 1 provides the ANOVA results for grade level, sex and the grade-by-sex interaction separately for each learning environment and attitude/anxiety scale. Both the $F$ value and eta $^{2}$ statistic (representing the amount of variance accounted for) are provided for each dependent variable. Table 1 shows that statistically significant results emerged for: grade level for the learning environment scale of Involvement and every attitude/anxiety scale (Attitude to Mathematical Inquiry, Enjoyment of Mathematics and Mathematics Anxiety); sex for the two learning environment scales of Student Cohesiveness and Cooperation and for Enjoyment of Mathematics and Mathematics Anxiety; and the grade-by-sex interaction for Attitude to Mathematical Inquiry and Enjoyment of Mathematics.

Grade-level differences in learning environment and attitude/anxiety scales 
Table 2 provides for each learning environment and attitude/anxiety scale the average item mean, the average item standard deviation, and the ANOVA results repeated from Table 1. The average item mean is simply the scale mean divided by the number of items in a scale. It is useful for comparing the means of scales containing different numbers of items.

As well, Table 2 provides an effect size for the grade-level difference for each scale. Cohen's $d$ is the difference between the means for the two grade levels divided by the pooled standard deviation for each learning environment and attitudinal/anxiety scale. The effect size conveniently expresses a difference between two groups in standard deviation units. According to Cohen (1988), effect sizes range from small (0.2) to medium (0.5) to large $(0.8)$.

Table 2 shows that, for the four scales for which grade-level differences were statistically significant, scores were less favourable in Year 8 than in Year 7. That is, relative to students in Year 7, Year 8 students perceived less Involvement and reported a less positive Attitude to Mathematical Inquiry, less Enjoyment of Mathematics and greater Mathematics Anxiety. For these scales, effect sizes ranged from 0.25 to 0.51 standard deviations, which are in the small to medium range according to Cohen's (1988) criteria.

Table 2 Average item mean, average item standard deviation and grade-level difference (ANOVA result and effect size) for each learning environment and attitude/anxiety scale

\begin{tabular}{|c|c|c|c|c|c|c|}
\hline \multirow[t]{2}{*}{ Scale } & \multicolumn{2}{|c|}{ Item mean } & \multicolumn{2}{|c|}{ Item SD } & \multicolumn{2}{|c|}{ Difference } \\
\hline & Year 7 & Year 8 & Year 7 & Year 8 & $F$ & $\begin{array}{c}\text { Effect } \\
\text { size }\end{array}$ \\
\hline \multicolumn{7}{|l|}{ Learning Environment } \\
\hline Student Cohesiveness & 4.04 & 4.05 & 0.63 & 0.56 & 0.86 & 0.01 \\
\hline Teacher Support & 3.65 & 3.63 & 0.888 & 0.78 & 0.56 & -0.02 \\
\hline Involvement & 3.55 & 3.36 & 0.76 & 0.76 & $11.56 * *$ & -0.25 \\
\hline Cooperation & 3.83 & 3.81 & 0.77 & 0.71 & 1.09 & -0.02 \\
\hline \multicolumn{7}{|l|}{ Attitudes/Anxiety } \\
\hline Attitude to Maths Inquiry & 3.49 & 3.27 & 0.58 & 0.54 & $21.09 * *$ & -0.39 \\
\hline Enjoyment of Mathematics & 3.47 & 3.01 & 0.95 & 0.87 & $30.93 * *$ & -0.51 \\
\hline Mathematics Anxiety & 2.18 & 2.47 & 0.82 & 0.82 & $10.68 * *$ & 0.35 \\
\hline
\end{tabular}


However, because of the existence of significant grade-by-sex interactions for both Attitude to Mathematical Inquiry and Enjoyment of Mathematics (Table 1), grade-level differences for these two scales are revisited below.

Sex differences in learning environment and attitude/anxiety scales

Table 3 provides ANOVA results (repeated from Table 1) and effect sizes for sex differences for the seven learning environment and attitude/anxiety scales. Interestingly, females held somewhat more favourable perceptions than males for all four learning environment scales, but males had somewhat more favourable attitude/anxiety scores than females on all scales (i.e. a higher Attitude to Mathematical Inquiry scores, higher Enjoyment of Mathematics scores and lower Mathematics Anxiety scores).

These differences were statistically significant for four scales (Student Cohesiveness, Cooperation, Enjoyment of Mathematics and Mathematics Anxiety) for which effect sizes ranged from 0.32 to 0.44 standard deviations, which would be classified as small to modest according to Cohen's (1988) criteria.

Table 3 Average item mean, average item standard deviation and sex difference (ANOVA result and effect size) for each learning environment and attitude/anxiety scale

\begin{tabular}{|c|c|c|c|c|c|c|}
\hline \multirow[t]{2}{*}{ Scale } & \multicolumn{2}{|c|}{ Item mean } & \multicolumn{2}{|c|}{ Item SD } & \multicolumn{2}{|c|}{ Difference } \\
\hline & Male & Female & Male & Female & $F$ & $\begin{array}{c}\text { Effect } \\
\text { size }\end{array}$ \\
\hline \multicolumn{7}{|l|}{ Learning Environment } \\
\hline Student Cohesiveness & 3.89 & 4.15 & 0.61 & 0.56 & $24.27 * *$ & 0.44 \\
\hline Teacher Support & 3.57 & 3.68 & 0.75 & 0.86 & 1.72 & 0.13 \\
\hline Involvement & 3.38 & 3.46 & 0.77 & 0.75 & 2.19 & 0.11 \\
\hline Cooperation & 3.66 & 3.92 & 0.77 & 0.69 & $16.24 * *$ & 0.35 \\
\hline \multicolumn{7}{|l|}{ Attitudes/Anxiety } \\
\hline Attitude to Maths Inquiry & 3.40 & 3.33 & 0.61 & 0.54 & 0.94 & -0.12 \\
\hline Enjoyment of Mathematics & 3.37 & 3.07 & 0.95 & 0.89 & $9.49 * *$ & -0.32 \\
\hline Mathematics Anxiety & 2.20 & 2.46 & 0.81 & 0.83 & $7.90 * *$ & 0.32 \\
\hline
\end{tabular}


However, because of the existence of a significant grade-by-sex interaction for Enjoyment of Mathematics (see Table 1), sex differences in Enjoyment need to be reconsidered below.

Interaction between grade level and sex

Table 1 shows that the grade-by-sex interaction was statistically significant for Attitude to Mathematical Inquiry and Enjoyment of Mathematics. This suggests that the interpretation of results for these two scales separately for grade level (Table 2) and sex (Table 3) are oversimplified. Therefore a graph of mean scores is provided for those two scales in Figure 1 in order to depict the scores of four groups: Year 7 males, Year 7 females, Year 8 males and Year 8 females.

For Attitude to Inquiry, scores were significantly higher in Year 7 than Year 8 (Table 2) but were similar overall for males and females (Table 3). Figure 1, however, suggests a more refined pattern. Although Inquiry scores were higher in Year 7 than Year 8 for students of both sexes, sex difference in Inquiry scores favoured males in Year 7 but favoured females in Year 8.

For Enjoyment, it previously was noted that scores were significantly higher for Year 7 than Year 8 (Table 2) and for males than females (Table 3). Figure 1 now can be used for a more sophisticated interpretation of grade-level and sex differences in Enjoyment. Although both males and females reported greater Enjoyment in Year 7 than Year 8, sex differences in Enjoyment favoured males in Year 7 but were virtually non-existent in Year 8. 

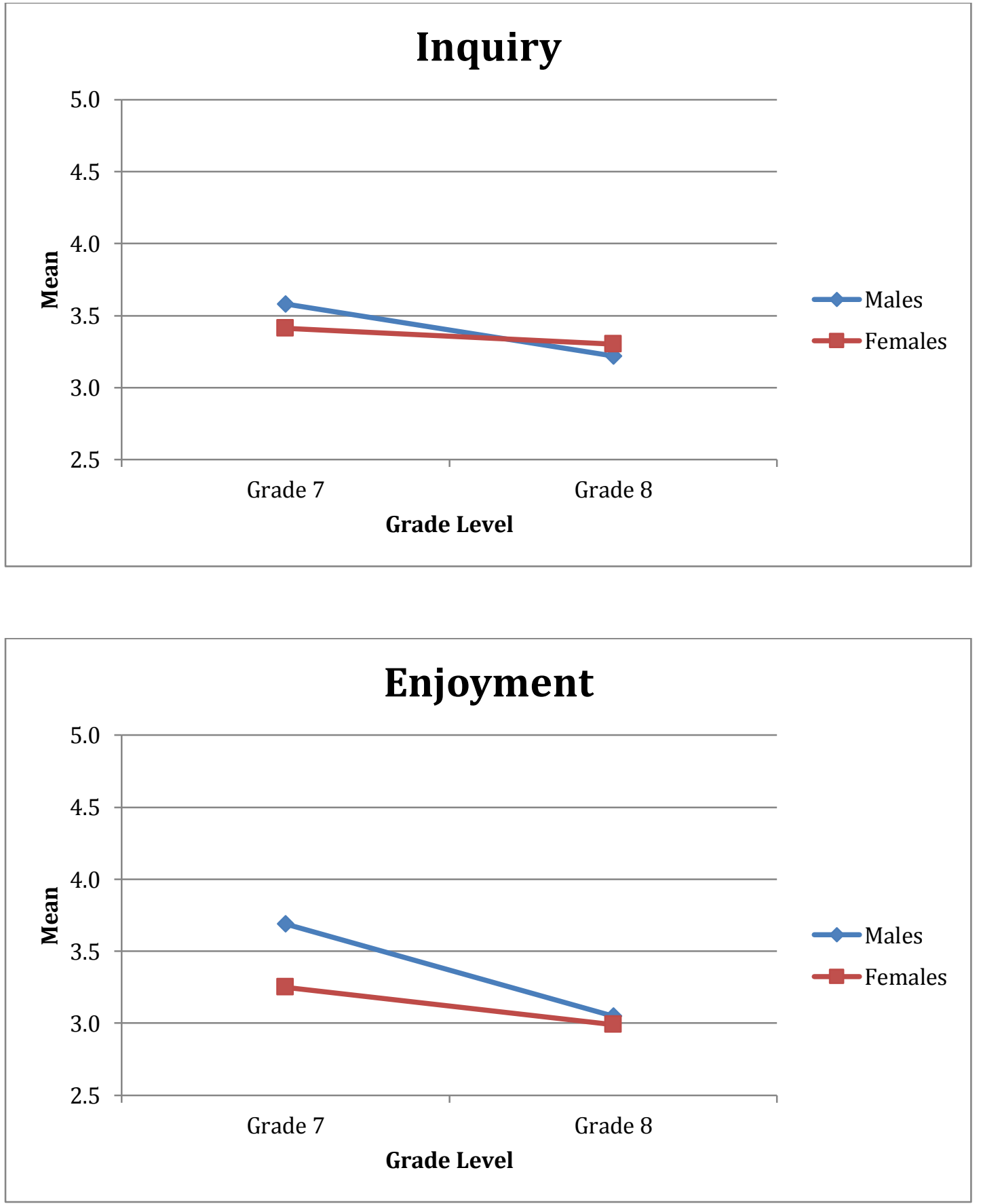

Figure 1: Grade-by-sex interactions for Attitude to Mathematical Inquiry and Enjoyment of Mathematics Lessons

\section{Discussion and conclusion}

This research built upon previous studies that utilised learning environment and attitude instruments in investigating changes during the transition from primary to secondary 
schooling, especially for the school subject of mathematics. This study contributes to the field of learning environments in that there have been very few prior studies of transition from year 7 to year 8 mathematics and its associated effect on the learning environment and students' attitudes/anxiety. The research (Deieso, 2017) also makes a methodological contribution by cross-validating widely-applicable learning environment, attitude and anxiety scales (WIHIC, TOMRA and MAM) in South Australian mathematics classrooms and thereby making these instruments more accessible to future researchers and teachers.

Our study of the primary-secondary school transition with 541 South Australian mathematics students revealed that, relative to year 7 students, year 8 students reported less involvement in their classroom environments and a deterioration in attitudes to mathematics (namely, attitude to inquiry, enjoyment and anxiety). This pattern largely replicates past primary-secondary transition research among: American mathematics students who experienced a deterioration in the classroom environment (Midgley et al. 1991); Tasmanian science students who experienced a deterioration in teacher-student relationships, although changes differed with student gender and the size of the primary school (Ferguson and Fraser 2009); and South Australian mathematics students who perceived a deterioration in many dimensions of the classroom learning environment (Hine 2001). Interestingly in both Hine's study and our study in South Australia, students perceived a significant decline in classroom involvement across transition of approximately a quarter of a standard deviation.

Practical benefits of this research are that teachers potentially could gain greater awareness and understanding of this critical transition period and implement strategies to alleviate its negative effects on the learning environment and students' attitudes and anxiety. From a practical perspective, teachers could use our instruments in attempts to improve their own classroom learning environments, perhaps using approaches described by Fraser and Aldridge (2017). 
As in all educational studies, our sample was of limited size and scope. A limited sample size limits the statistical power of data analyses. With a more-representative sample, one can more confidently generalise findings to a wider population. Therefore, in future research on transition, larger and more representative samples are recommended.

Another possible limitation is that we did not include qualitative methods. Tobin and Fraser (1998) advocate the combining of quantitative and qualitative approaches within learning environment studies to complement and reinforce each other, thereby making the study's findings more dependable, robust and clear. For example, Fraser's (1999) study involved multiple researchers utilising observations, student diaries, video recordings and field notes, as well as interviews with teachers, students, parents and administrators, whereas Aldridge, Fraser and Huang (1999) made use of narrative stories, observations and interviews. In future studies of transition between educational levels, the combining of quantitative and qualitative methods is desirable.

A limitation of our study's design was that it was cross-sectional (i.e. the year 7 sample involved different students from the year 8 sample) rather than longitudinal (i.e. the same students who comprised the year 7 sample also made up the year 8 sample) as in the case of Ferguson and Fraser (1999) and Hine (2001). However, longitudinal transition studies also have their limitations in that they present considerable logistical problems in trying to track students from a large number of feeder primary schools to a smaller number of linked secondary schools.

Because of the widespread use of and rapid development of technology, electronic versions of our questionnaires could be developed for future on-line use to make the researchers' task easier, create a better environment for delivering, collecting and storing surveys, and reduce the carbon footprint of printed questionnaires. 
Our study involving learning environment and attitude/anxiety criteria yielded many valuable results. However, it would be desirable in future transition studies also to include measures of mathematics achievement and other valued educational outcomes (e.g. critical thinking, mental health).

The methods of data analysis employed in our study (e.g. exploratory factor analysis, MANOVA) were appropriate and sophisticated and yielded significant insights. However, in future research, it could be worthwhile to supplement these approaches with other dataanalysis methods such as confirmatory factor analysis, hierarchical linear model (HLM) analysis and structural equation modelling (SEM). 


\section{Appendix A}

Factor Analysis Results for Learning Environment Scales

\begin{tabular}{|c|c|c|c|c|}
\hline \multirow[t]{2}{*}{ Item } & \multicolumn{4}{|c|}{ Factor Loadings } \\
\hline & $\begin{array}{l}\text { Student } \\
\text { Cohesiveness }\end{array}$ & $\begin{array}{l}\text { Teacher } \\
\text { Support }\end{array}$ & Involvement & Cooperation \\
\hline SC1 & 0.64 & & & \\
\hline $\mathrm{SC} 2$ & 0.42 & & & \\
\hline SC3 & 0.55 & & & \\
\hline $\mathrm{SC} 4$ & 0.72 & & & \\
\hline SC5 & 0.57 & & & \\
\hline SC6 & 0.37 & & & \\
\hline SC7 & 0.62 & & & \\
\hline SC8 & 0.35 & & & \\
\hline TS1 & & 0.64 & & \\
\hline $\mathrm{TS} 2$ & & 0.73 & & \\
\hline TS3 & & 0.71 & & \\
\hline TS4 & & 0.66 & & \\
\hline TS5 & & 0.72 & & \\
\hline TS6 & & 0.75 & & \\
\hline TS7 & & 0.69 & & \\
\hline TS8 & & 0.61 & & \\
\hline IN1 & & & 0.73 & \\
\hline IN2 & & & 0.80 & \\
\hline IN3 & & & 0.47 & \\
\hline IN4 & & & 0.62 & \\
\hline IN5 & & & 0.41 & \\
\hline IN6 & & & 0.58 & \\
\hline IN7 & & & 0.42 & \\
\hline IN8 & & & 0.44 & \\
\hline $\mathrm{CO} 1$ & & & & 0.53 \\
\hline $\mathrm{CO} 2$ & & & & 0.54 \\
\hline $\mathrm{CO} 3$ & & & & 0.56 \\
\hline $\mathrm{CO} 4$ & & & & 0.61 \\
\hline $\mathrm{CO} 5$ & & & & 0.47 \\
\hline $\mathrm{CO} 6$ & & & & 0.61 \\
\hline CO7 & & & & 0.59 \\
\hline $\mathrm{CO} 8$ & & & & 0.60 \\
\hline$\%$ Variance & 5.73 & 35.98 & 4.04 & 9.51 \\
\hline igenvalue & 1.83 & 11.51 & 1.29 & 3.04 \\
\hline lpha reliability & 0.83 & 0.90 & 0.87 & 0.87 \\
\hline
\end{tabular}

$N=541$ students

Factor loadings less than 0.35 have been omitted from the table.

Principal axis factoring with varimax rotation and Kaiser normalisation 


\section{Appendix B}

Factor Analysis Results for Attitude and Anxiety Scales

\begin{tabular}{|c|c|c|c|}
\hline \multirow[t]{2}{*}{ Item } & \multicolumn{3}{|c|}{ Factor Loadings } \\
\hline & Maths Inquiry & Maths Enjoyment & Maths Anxiety \\
\hline MI1 & 0.46 & & \\
\hline MI2 & 0.37 & & \\
\hline MI3 & 0.36 & & \\
\hline MI4 & 0.47 & & \\
\hline MI5 & 0.35 & & \\
\hline MI6 & 0.43 & & \\
\hline MI7 & 0.57 & & \\
\hline MI8 & 0.60 & & \\
\hline MI9 & 0.35 & & \\
\hline MI10 & 0.59 & & \\
\hline ME1 & & 0.82 & \\
\hline ME2 & & 0.76 & \\
\hline ME3 & & 0.64 & \\
\hline ME4 & & 0.73 & \\
\hline ME5 & & 0.74 & \\
\hline ME6 & & 0.52 & \\
\hline ME7 & & 0.87 & \\
\hline ME8 & & 0.49 & \\
\hline ME9 & & 0.86 & \\
\hline ME10 & & 0.67 & \\
\hline MAM1 & & & 0.43 \\
\hline MAM2 & & & 0.68 \\
\hline MAM3 & & & 0.55 \\
\hline MAM4 & & & 0.68 \\
\hline MAM5 & & & 0.66 \\
\hline MAM6 & & & 0.67 \\
\hline MAM7 & & & 0.76 \\
\hline MAM8 & & & 0.62 \\
\hline$\%$ Variance & 7.46 & 29.59 & 11.76 \\
\hline Eigenvalue & 2.08 & 8.28 & 3.29 \\
\hline Alpha reliability & 0.96 & 0.65 & 0.85 \\
\hline
\end{tabular}

$N=541$ students

Factor loadings less than 0.35 have been omitted from the table.

Principal axis factoring with varimax rotation and Kaiser normalisation. 


\section{References}

Aarnos, E., \& Perkkila, P. (2012). Early signs of mathematics anxiety? Procedia - Social and Behavioral Sciences, 46, 1495-1499.

Abbasi, M., Samadzadeh, M., \& Shahbazzadegan, B. (2013). Study of mathematics anxiety in high school students and its relationship with self-esteem and teachers' personality characteristics. Procedia - Social and Behavioral Sciences, 83, 672-677.

Afari, E., Aldridge, J. M., Fraser, B. J., \& Khine, M. S. (2013). Students' perceptions of the learning environment and attitudes in game-based mathematics classrooms. Learning Environments Research, 16, 131-150.

Aiken, L.R. (2002). Attitudes and related psychosocial constructs: Theories, assessment, and research. Thousand Oaks, CA: Sage Publications.

Aldridge, J. M., \& Fraser, B. J. (2000). A cross-cultural study of classroom learning environments in Australia and Taiwan. Learning Environments Research, 3, 101-134.

Aldridge, J. M., \& Fraser, B. J. (2008). Outcomes-focused learning environments: Determinants and effects (Advances in Learning Environments research series). Rotterdam, The Netherlands: Sense Publishers.

Aldridge, J. M., Fraser, B. J., \& Huang, I. T.-C. (1999). Investigating classroom environments in Taiwan and Australia with multiple research methods. Journal of Educational Research, 93, 48-62.

Aldridge, J. M., Fraser, B. J., \& Sebela, M. P. (2004). Using teacher action research to promote constructivist learning environments in South Africa. South African Journal of Education, 24(4), 245-253. 
Allen, D., \& Fraser, B. J. (2007). Parent and student perceptions of classroom learning environment and its association with student outcomes. Learning Environments Research, 10, 67-82.

Allport, G.W. (1935). Attitudes. In C. Murchison (Ed.), Handbook of social psychology (pp. 798-844). Worcester, MA: Clark University Press.

Al Mutawah, M. A. (2015). The influence of mathematics anxiety in middle and high school on students' math achievement. International Education Studies, 8(11), 239-252.

Anderman, E. M., \& Midgley, C. (1997). Changes in achievement goal orientations, perceived academic competence, and grades across transition to middle-level schools. Contemporary Educational Psychology, 22, 269-298.

Ashton, R. (2008). Children's views and transition. Improving the transfer to secondary school: How every child's voice can matter. Support for Learning, 23(4), 176-182.

Bru, E., Stornes, T., Munthe, E., \& Thuen, E. (2010). Students' perception of teacher support across the transition from primary to secondary school. Scandinavian Journal of Educational Research, 54(6), 519-533.

Burden, R. L., \& Fraser, B. J. (1993). Use of classroom environment assessments in school psychology: A British perspective. Psychology in the Schools, 30(3), 232-240.

Byrne, D. B., Hattie, J. A., \& Fraser, B. J. (1986). Student perceptions of preferred classroom learning environment. The Journal of Educational Research, 80(1), 10-18.

Catlioglu, H., Birgin, O., Costu, S., \& Gurbuz, R. (2009). The level of mathematics anxiety among pre-service elementary school teachers. Procedia Social and Behavioral Sciences, $1,1578-1581$.

Charalampous, K., \& Kokkinos, C. M. (2017). The Greek elementary "What Is Happening In this Class?'(G-EWIHIC): A three-phase multi-sample mixed-methods study. Studies in Educational Evaluation, 52, 55-70. 
Chionh, Y. H., \& Fraser, B. J. (2009). Classroom environment, achievement, attitudes and self-esteem in geography and mathematics in Singapore. International Research in Geographical and Environmental Education, 18, 29-44.

Chipangura, A., \& Aldridge, J. (2016). Impact of multimedia on students' perceptions of the learning environment in mathematics classrooms. Learning Environments Research, $20,121-138$.

Cohen, J. (1988). Statistical power analysis for the behavioral sciences ( $2^{\text {nd }}$ ed.). New York: Academic Press.

Cohn, S. T., \& Fraser, B. J. (2016). Effectiveness of student response systems in terms of learning environment, attitudes and achievement. Learning Environments Research, $19,153-167$.

Crypton, D. (1981). Mathophobia: A disastrous hang-up. Science Digest, July, 121-123.

Deieso, D. (2017). Changes in learning environment and students' attitudes and anxiety associated with the transition from primary to secondary school mathematics. Unpublished PhD thesis, Curtin University.

Dorman, J. P. (2003). Cross-national validation of the What Is Happening In this Class? (WIHIC) questionnaire using confirmatory factor analysis. Learning Environments Research, 6, 231-245.

Dorman, J. P. (2008). Use of multitrait-multimethod modelling to validate actual and preferred forms of the What Is Happening In this Class? (WIHIC) questionnaire. Learning Environments Research, 11, 179-193.

Eccles, J. S., Midgley, C., Wigfield, A., Buchanan, C. M., Reuman, D., Flanagan, C., \& MacIver, D. (1993). Development during adolescence. The impact of StageEnvironment fit on young adolescents' experiences in schools and in families. American Psychologist, 48(2), 90-101. 
Feldlaufer, H., Midgley, C., \& Eccles, J.S. (1988). Student, teacher, and observer perceptions of the classroom environment before and after the transition to junior high school. The Journal of Early Adolescence, 8, 133-156.

Ferguson, P. D., \& Fraser, B. J. (1999). Changes in learning environment during the transition from primary to secondary school. Learning Environments Research, 1, 369-383.

Finlayson, M. (2014). Addressing math anxiety in the classroom. Improving Schools, 17(1), 99-115.

Fraser, B. J. (1978). Development of a test of science related attitudes. Science Education, 62, 509-515.

Fraser, B. J. (1981a). Using environmental assessments to make better classrooms. Journal of Curriculum Studies, 13(2), 131-144.

Fraser, B. J. (1981b). Test of science-related attitudes (TOSRA). Melbourne, Australia: Australian Council for Educational Research.

Fraser, B. J. (1982). Individualized classroom environment questionnaire. American Journal of Evaluation, 3(2), 72-73.

Fraser, B. J. (1999). "Grain sizes" in learning environment research: Combining qualitative and quantitative methods. In H. C. Waxman \& H. J. Walberg (Eds.), New directions for teaching practice and research (pp. 285-296). Berkeley, CA: McCutchan.

Fraser, B. J. (2007). Classroom learning environments. In S. K. Abell \& N.G. Lederman (Eds.), Handbook of research on science education (pp. 103-124). Mahwah, NJ: Lawrence Erlbaum Associates.

Fraser, B. J. (2012). Classroom learning environments: Retrospect, context and prospect. In B. J. Fraser, K. G. Tobin, \& C. J. McRobbie (Eds.), Second international handbook of science education (pp. 1191-1239). New York: Springer. 
Fraser, B. J. (2014). Classroom learning environments: Historical and contemporary perspectives. In N. G. Lederman \& S. K. Abell (Eds.), Handbook of research on science education (pp. 104-119). New York: Routledge.

Fraser, B. J., \& Aldridge, J. M. (2017). Improving classrooms through assessment of learning environment. In J. P. Bakken (Ed.), Classrooms Volume 1: Assessment practices for teachers and student improvement strategies (pp. 91-107). New York: Nova Science Publishers.

Fraser, B. J., Aldridge, J. M., \& Adolphe, F. S. (2010). A cross-national study of science classroom environments in Australia and Indonesia. Research in Science Education, $40,551-571$.

Fraser. B. J., \& Butts, W. L. (1982). Relationship between perceived levels of classroom individualization and science-related attitudes. Journal of Research in Science Teaching, 19(2), 143-154.

Fraser, B. J., \& Fisher, D. L. (1983). Development and validation of short forms of some instruments measuring student perceptions of actual and preferred classroom learning environment. Science Education, 67 (1), 115-131.

Fraser, B. J., Giddings, G. J., \& McRobbie, C. J. (1995). Evolution and validation of a personal form of an instrument for assessing science laboratory classroom environments. Journal of Research in Science Teaching, 32(4), 399-422.

Fraser, B. J., \& Kahle, J. B. (2007). Classroom, home and peer environment influences on student outcomes in science and mathematics: An analysis of systemic reform data. International Journal of Science Education, 29, 1891-1909.

Fraser, B. J., \& Lee, S. S. U. (2009). Science laboratory classroom environments in Korean high schools. Learning Environments Research, 12, 67-84. 
Fraser, B. J., McRobbie, C. J. \& Fisher, D. L. (1996, April). Development, validation and use of personal and class forms of a new classroom environment instrument. Paper presented at the annual meeting of the American Educational Research Association, New York.

Fraser, B. J., \& Tobin, K. G. (Eds.). (1987). Exemplary practice in science and mathematics education. Perth: Key Centre for School Science and Mathematics, Curtin University.

Galton, M., \& Morrison, I. (2000). Concluding comments. Transfer and transition: The next steps. International Journal of Educational Research, 33, 443-449.

Goh, S. C., \& Fraser, B. J. (2000). Teacher interpersonal behaviour and elementary students' outcomes. Journal of Research in Childhood Education, 14(2), 216-231.

Gough, M. F. (1954). Mathemaphobia: Causes and treatments. Clearing House, 28, 290-294.

Guillen, M. (1984). Bridges to infinity. London, UK. Rider \& Company.

Hayes, D., \& Chodkiewicz, A. (2006). School-community links: Supporting learning in the middle years. Research Papers in Education, 21(1), 3-18.

Helding, K. A., \& Fraser, B. J. (2013). Effectiveness of NBC (National Board Certified) teachers in terms of learning environment, attitudes and achievement among secondary school students. Learning Environments Research, 16, 1-21.

Hine, P. (2001). Classroom environment and the transition to secondary schooling. Unpublished PhD thesis, Curtin University.

Hopko, D. R., Mahadevan, R., Bare, R. L., \& Hunt, M. K. (2003). The Abbreviated Math Anxiety Scale (AMAS): Construction, validity, and reliability. Assessment, 10(2), 178-182.

Hunt, G. E. (1985). Math anxiety-Where do we go from here? Focus on Learning Problems in Mathematics, 7(2), 29-40. 
Idiris, S., \& Fraser, B. J. (1997). Psychosocial environment of agricultural science classrooms in Nigeria. International Journal of Science Education, 19, 79-91.

Haciomeroglu, G. (2013). Mathematics anxiety and mathematical beliefs: What is the relationship in elementary pre-service teachers? IUMPST: The Journal, 5, 1-9.

Jackson, C. D., \& Leffingwell, R. J. (1999). The role of instructors in creating math anxiety in students from kindergarten through college. Mathematics Teacher, 92(7), 583-586.

Jansen, B. R. J., Louwerse, J., Straatemeier, M., Van der Ven, S. H. G., Klinkenberg, S., \& Van der Maas, H. L. J. (2013). The influence of experiencing success in math on math anxiety, perceived math competence, and math performance. Learning and Individual Differences, 24, 190-197.

John-Henderson, N. A., Rheinschmidt, M. L., \& Mendoza-Denton, R. (2015). Cytokine responses and math performance: The role of stereotype threat and anxiety reappraisals. Journal of Experimental Social Psychology, 56, 203- 206.

Kaiser, H. (1974). An index of factorial simplicity. Psychometrika, 39, 31-36.

Khine, M. S. (Ed.). (2015). Attitude measurements in science education: Classic and contemporary approaches. Charlotte, NC: Information Age Publishing.

Khine, M. S., Fraser, B. J., Afari, E., Oo, Z., \& Kyaw, T. T. (in press). Student perceptions of the learning environment in tertiary science classrooms in Myanmar. Learning Environments Research. doi 10.10077s10984-017-9250-0

Khoo, H. S., \& Fraser, B. J. (2008). Using classroom psychosocial environment in the evaluation of adult computer application courses in Singapore. Technology, Pedagogy and Education, 17(1), 67-81.

Kim, H. B., Fisher, D. L., \& Fraser, B. J. (2000). Classroom environment and teacher interpersonal behaviour in secondary science classrooms in Korea. Evaluation and Research in Education, 14, 3-22. 
Kind, P.K., \& Barmby, P. (2011). Defending attitude scales. In I. M. Saleh and M. S. Khine (Eds.), Attitude research in science education: Classic and contemporary measurements (pp. 117-135). Charlotte, NC: Information Age Publishing.

Kind, P., Jones, K., \& Barmby, P. (2007). Developing attitudes towards science measures. International Journal of Science Education, 29, 871-893.

Koh, N. K., \& Fraser, B. J. (2014). Learning environments associated with use of mixed mode delivery model among secondary business studies students in Singapore. Learning Environments Research, 17, 157-171.

Koul, R. B., \& Fisher, D. L. (2005). Cultural background and students' perceptions of science classroom learning environment and teacher interpersonal behaviour in Jammu, India. Learning Environments Research, 8, 195-211.

Kvedere, L. (2014). Mathematics self-efficacy, self-concept and anxiety among 9th grade students in Latvia. Procedia - Social and Behavioral Sciences, 116, 2687-2690.

Lewin, K. (1936). Principles of topological psychology. New York: McGraw.

Lim, C.-T. D., \& Fraser, B. J. (2017). Learning environments in research in English classrooms. Unpublished paper, Curtin University.

MacLeod, C., \& Fraser, B. J. (2010). Development, validation and application of a modified Arabic translation of the What Is Happening In this Class? (WIHIC) questionnaire. Learning Environments Research, 13, 105-125.

Maher, D. (2010). Supporting students' transition from primary school to high school using the internet as a communication tool. Technology, Pedagogy and Education, 19(1), 17-30.

Marchis, I. (2011). Factors that influence secondary school students' attitude to mathematics. Procedia - Social and Behavioral Sciences, 29, 786-793. 
Martin-Dunlop, C., \& Fraser, B. J. (2008). Learning environment and attitudes associated with an innovative science course designed for prospective elementary teachers. International Journal of Science and Mathematics Education, 6(1), 163-190.

McRobbie, C. J., \& Fraser, B. J. (1993). Associations between student outcomes and psychosocial science environment. The Journal of Educational Research, 87(2), 7885.

Midgley, C., Eccles, J. S., \& Feldlaufer, H. (1991). Classroom environment and the transition to junior high school. In B. J. Fraser and H. J. Walberg (Eds.), Educational environments: Evaluation, antecedents and consequences (pp. 113-139). London: Pergamon Press.

Midgley, C., Feldlaufer, H., \& Eccles, J. S. (1989). Student/teacher relations and attitudes toward mathematics before and after the transition to junior high school. Child Development, 60(4), 981-992.

Moos, R. H. (1974). The social climate scales: An overview. Palo Alto, CA: Consulting Psychologists Press.

Moos, R. H., \& Trickett, E. J. (1974). Classroom Environment Scale manual. Palo Alto, CA: Consulting Psychologists Press.

Munby, H. (1997). Issues of validity in science attitude measurement. Journal of Research in Science Teaching, 34, 337-341.

Murray, H. A. (1938). Explorations in personality. New York: Oxford University Press.

Noyes, A. (2006). School transfer and the diffraction of learning trajectories. Research Papers in Education, 21(1), 43-62.

Ogbuehi, P. I., \& Fraser, B. J. (2007). Learning environment, attitudes and conceptual development associated with innovative strategies in middle-school mathematics. Learning Environments Research, 10, 101-114. 
Olmez, I. B., \& Ozel, S. (2012). Mathematics anxiety among sixth and seventh grade Turkish elementary school students. Procedia - Social and Behavioral Sciences, 46, 49334937.

Osborne, J., Simons, S., \& Collins, S. (2003). Attitudes towards science: A review of the literature and its implication. International Journal of Science Education, 25, 10491079.

Peiro, M. M., \& Fraser, B. J. (2009). Assessment and investigation of science learning environments in the early childhood grades. In M. Ortiz \& C. Rubio (Eds.), Educational evaluation: 21st century issues and challenges (pp. 349-365). New York: Nova Science Publishers.

Perso, T. (2005). Teaching mathematics in the middle years: Is middle school necessary? Australian Mathematics Teacher, 61(1), 25-31.

Plake, B. S., \& Parker, C. S. (1982). The development and validation of a revised version of the Mathematics Anxiety Rating Scale. Educational and Psychological Measurement, $42,551-557$.

Primi, C., Busdraghi, C., Tomasetto, C., Morsanyi, K., \& Chiesi, F. (2014). Measuring math anxiety in Italian college and high school students: Validity, reliability and gender invariance of the Abbreviated Math Anxiety Scale (AMAS). Learning and Individual Differences, 34, 51-56.

Ramirez, G., Gunderson, E. A., Levine, S. C., \& Beilock, S. L. (2013). Math anxiety, working memory, and math achievement in early elementary school. Journal of Cognition and Development, 14(2), 187-202.

Rice, J. K. (1997). The disruptive transition from middle to high school: Opportunities for linking policy and practice. Journal of Education Policy, 12(5), 403-417. 
Rice, J. K. (2001). Explaining the negative impact of the transition from middle to high school on student performance in mathematics and science. Educational Administration Quarterly, 37(3), 372-400.

Richardson, F. C., \& Suinn, R. M. (1972). The Mathematics Anxiety Rating Scale: Psychometric data. Journal of Counseling Psychology, 19(6), 551-554.

Sarkar, A., Dowker, D., \& Kadosh, R. C. (2014). Cognitive enhancement or cognitive cost: Trait-specific outcomes of brain stimulation in the case of mathematics anxiety. The Journal of Neuroscience, 34(50), 16605-16610.

Scarpello, G. (2007). Helping students get past math anxiety. Techniques: Connecting Education \& Careers, 82(6), 34-35.

Schacht, S., \& Stewart, B. J. (1990). What's funny about statistics? A technique for reducing anxiety. Teaching Sociology, 18(1), 52-56.

Sengul, S., \& Dereli, M. (2010). Does instruction of 'Integers' subject with cartoons affect students' mathematics anxiety? Procedia - Social and Behavioral Sciences, 2, 21762180.

Singh, M., \& McNeil, J. T. (2014). Do learning environments differ across subjects and nations: Case studies in Hawaii and Singapore using the WIHIC questionnaire. Learning Environments Research, 17(2), 173-189.

Spinner, H., \& Fraser, B. J. (2005). Evaluation of an innovative mathematics program in terms of classroom environment, student attitudes, and conceptual development. International Journal of Science and Mathematics Education, 3, 267-293.

Stern, G. G., Stein, M. I., \& Bloom, B. S. (1956). Methods in personality assessment. Glencoe, IL: Free Press. 
Supekar, K., Iuculano, T., Chen, L., \& Menon, V. (2015). Remediation of childhood math anxiety and associated neural circuits through cognitive tutoring. The Journal of Neuroscience, 35(36), 12574-12583.

Taylor, P. C., Fraser, B. J., \& Fisher, D. L. (1997). Monitoring constructivist classroom learning environments. International Journal of Educational Research, 27, 293-302.

Thompson, B. (1998). Review of 'what if there were no significance tests?' Educational and Psychological Measurement, 58, 334-346.

Tobin, K., \& Fraser, B. (1998). Qualitative and quantitative landscapes of classroom learning environments. In B. J. Fraser \& K. G. Tobin (Eds.), The international handbook of science education (pp. 623-640). Dordrecht, The Netherlands: Kluwer Academic Publishers.

Tytler, R., \& Osborne, J. (2012). Student attitudes and aspirations towards science. In B. J. Fraser, K. G. Tobin and C. J. McRobbie (Eds.), Second international handbook of science education (pp. 597-625). New York: Springer.

Urdan, T. C. (2010). Statistics in plain English ( $3^{\text {rd }}$ ed.). New York: Routledge.

Verkijika, S. F., \& De Wet, L. (2015). Using a brain-computer interface (BCI) in reducing math anxiety: Evidence from South Africa. Computers \& Education, 81, 113-122.

Wang, Z., Hart, S. A., Kovas, Y., Lukowski, S., Soden, B., Thompson, L. A., \& Petrill, S. A. (2014). Who is afraid of math? Two sources of genetic variance for mathematical anxiety. The Journal of Child Psychology and Psychiatry, 55(9), 1056-1064. doi: 10.1111/jcpp.12224.

Wahyudi, \& Treagust, D. F. (2004). The status of science classroom learning environments in Indonesian lower secondary schools. Learning Environments Research, 7, 43-63.

Walberg, H. J., \& Anderson, G.J. (1968). Classroom climate and individual learning. Journal of Educational Psychology, 59, 414-419. 
Waldrip, B. G., Fisher, D. L., \& Dorman, J. (2009). Identifying exemplary science teachers through students' perceptions of their learning environment. Learning Environments Research, 12, 1-13.

Wolf, S. J., \& Fraser, B. J. (2008). Learning environment, attitudes and achievement among middle-school science students using inquiry-based laboratory activities. Research in Science Education, 38, 321-341.

Wong, A. F. L., \& Fraser, B. J. (1996). Environment-attitude associations in the chemistry laboratory classroom. Research in Science and Technological Education, 14, 91-102.

Wubbels, Th., \& Brekelmans, M. (2012). Teacher-students relationships in the classroom. In B. J., Fraser, K. G. Tobin, and C. J. McRobbie (Eds.), Second international handbook of science education (pp. 1241-1255). New York: Springer.

Wubbels, Th., \& Levy, J. (1991). A comparison of inter-personal behavior of Dutch and American teachers. International Journal of Intercultural Relationships, 15, 1-18.

Yang, X. (2015). Rural junior secondary school students' perceptions of classroom learning environments and their attitude and achievement in mathematics in West China. Learning Environments Research, 18(2), 249-266.

Yaratan, H., \& Kasapoglu, L. (2012). Eighth grade students' attitude, anxiety, and achievement pertaining to mathematics lessons. Procedia - Social and Behavioral Sciences, 46, 162-171.

Yarrow, A., Millwater, J., \& Fraser, B.J. (1997). Improving university and primary school classroom environments through preservice teachers' action research. International Journal of Practical Experiences in Professional Education, 1, 68-93.

Young, C. B., Wu, S. S., \& Menon, V. (2012). The neurodevelopmental basis of math anxiety. Psychological Science, 23(5), 492-501. 
Zandvliet, D. B., \& Fraser, B. J. (2004). Learning environments in information and communication technology classrooms. Technology, Pedagogy and Education, 13, 97-123.

Zaragoza, J. M., \& Fraser, B. J. (2017). Field-study science classrooms as positive and enjoyable learning environments. Learning Environments Research, 20(1), 1-20.

Zeedyk, M. S., Gallacher, J., Henderson, M., Hope, G., Husband, B., \& Lindsay, K. (2003). Negotiating the transition from primary to secondary school: Perceptions of pupils, parents and teachers. School Psychology International, 24, 67-79. 